\title{
Environmental Impact of Geothermal Power Plants
}

\author{
Mladen BOŠNJAKOVIĆ, Marinko STOJKOV, Mate JURJEVIĆ
}

\begin{abstract}
Today, there is a growing awareness of the need for environmental protection and a healthy ecological environment. Given the growing popularity of renewable energy sources, they should be familiar with their environmental impact. Each renewable energy source has more or less environmental impacts that are most often compared to the influence of conventional fuels on the environment. The aim of this article is to show the potential impacts of geothermal power plants on the environment both in the construction phase and in the phase of regular work. Environmental impacts may be temporary or irreversible and include changes in habitats and land use, atmospheric emissions, increased noise, impact on surface and groundwater, land subsidence, occurrence of seismicity and solid waste disposal. The magnitude of the influence depends on the characteristics of the geothermal source, the applied thermodynamic cycle, and the applied abatement systems.
\end{abstract}

Keywords: environment; geothermal power plant; impact

\section{INTRODUCTION}

Recently, it has been discovered that in Croatia there is a much greater geothermal potential for producing electrical and thermal energy than previously assumed. In Pannonian basin in the Republic of Croatia, there is a certain number of medium-temperature geothermal sources that can produce electricity: Velika Ciglena, Lunjkovec-Kutnjak, Ferdinandovac, Recica, Legrad, Mali Bukovec, Babina Greda, Draškovec and Kotoriba [1].

During 2018, the geothermal power plant of Velika Ciglena near town Bjelovar was put into operation with a gross power of 16,5 MW, and during 2019 the operation of the geothermal power plant Draškovec with a gross power of $18,6 \mathrm{MW}$ is planned. In the forthcoming period, construction of a $25 \mathrm{MW}$ power plant on the LunjkovecKutnjak geothermal field can be expected.

The geothermal power plant Velika Ciglena consists of two wells depth of 4,700 meters i.e. 3,000 meters, spaced a few hundred meters away. Two impingement wells are far from extensive wells between two and three kilometers, and deep about $3000 \mathrm{~m}$. The water temperature at the production wells is about $175^{\circ} \mathrm{C}$.

At the "Kotoriba" exploration site at a depth of about $3500 \mathrm{~m}$ there is a geothermal water with a temperature above $150{ }^{\circ} \mathrm{C}$, while at a depth of $4000 \mathrm{~m}$ the water temperature of $200{ }^{\circ} \mathrm{C}$ is expected.

Geothermal energy can be exploited for a long time with proper usage and can bring positive economic effects to Croatia. An important fact is that the geothermal power plants are a stable source of electricity for the power grid, as they supply electricity 24 hours a day throughout the year and can be an excellent substitute for wind and solar power plants whose work depends heavily on weather conditions.

As there is growing interest in geothermal energy in Europe as well as in Croatia, it is important to be familiar with the potential impact of geothermal power plants on the environment and the latest technology solutions that reduce these impacts. Geothermal energy is generally considered to be an environmentally friendly source of energy, especially in relation to fossil fuels. However, the use of geothermal energy in the past 40 years has shown that there are adverse impacts on the environment. There is an increasing interest in these impacts to a degree that may be a limiting factor for further use of geothermal energy. History shows that ignoring or neglecting such problems can have a bad impact on industry development, as it can cause a loss of confidence from the public and financial sectors. If the goal is to further develop geothermal energy applications, all environmental impacts should be clearly recognized as well as protective measures so as to avoid or reduce their impact on the environment. An environmental impact assessment should be carried out to identify and quantify all possible and actual impacts, and to ensure proper monitoring of plant condition as well as protocols for potential accidents. Much attention is also required during project preparation, plant design and start-up phase (Tab. 1).

Table 1 The potential environmental impacts of geothermal power plant [2]

\begin{tabular}{|c|c|c|c|}
\hline & \multirow{2}{*}{$\begin{array}{l}\text { Low- } \\
\text { temp. } \\
\text { system }\end{array}$} & \multicolumn{2}{|c|}{ High-temp. system } \\
\hline & & $\begin{array}{l}\text { Vapour- } \\
\text { dominated }\end{array}$ & $\begin{array}{l}\text { Liquid- } \\
\text { dominated }\end{array}$ \\
\hline \multicolumn{4}{|l|}{ Drilling operations } \\
\hline Deforestation and soil erosion & * & $* *$ & ** \\
\hline Noise & ** & $\star \star *$ & $\star \star$ \\
\hline $\begin{array}{l}\text { Contamination of ground } \\
\text { water with drilling fluid }\end{array}$ & * & ** & ** \\
\hline \multicolumn{4}{|l|}{ Mass withdrawal } \\
\hline $\begin{array}{l}\text { Degradation of thermal } \\
\text { features }\end{array}$ & * & ** & $* * *$ \\
\hline Ground subsidence & * & ** & $\star * *$ \\
\hline Depletion of groundwater & $\mathrm{O}$ & * & $\star \star$ \\
\hline Hydrothermal eruptions & $\mathrm{O}$ & * & ** \\
\hline Ground temp. change & $\mathrm{O}$ & * & ** \\
\hline \multicolumn{4}{|l|}{ Disposal of wasted liquid } \\
\hline \multicolumn{4}{|l|}{ Impacts on living organ. } \\
\hline surface discharge & * & * & $\star \star * *$ \\
\hline reinjection & $\mathrm{O}$ & $\mathrm{O}$ & $\mathrm{O}$ \\
\hline \multicolumn{4}{|l|}{ Impacts on waterways } \\
\hline surface disposal & * & * & ** \\
\hline reinjection & $\mathrm{O}$ & $\mathrm{O}$ & $\mathrm{O}$ \\
\hline Contamination of groundwater & * & * & * \\
\hline Induced seismicity & $\mathrm{O}$ & ** & ** \\
\hline \multicolumn{4}{|l|}{ Disposal of wasted gas } \\
\hline Impacts on living organ. & $\mathrm{O}$ & $*$ & $* *$ \\
\hline Microclimate influences & $\mathrm{O}$ & * & * \\
\hline
\end{tabular}

O No effect, $*$ Little effect, $\star \star$ Moderate effect, $* \star *$ High effect

The potential environmental impact of the geothermal power plant is shown visually in Fig. 1. 


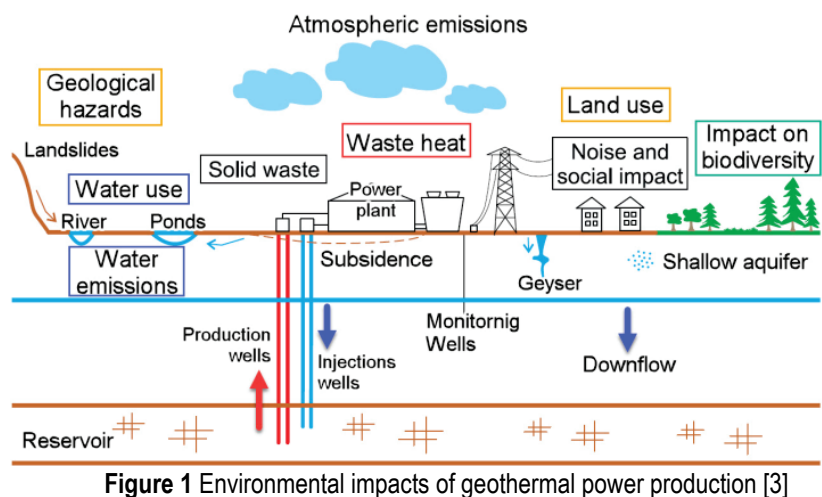

\section{THE POTENTIAL ENVIRONMENTAL IMPACT 2.1 Drilling Operations}

Utilization of both low temperature and hightemperature geothermal sources requires drilling up to depths of $500 \mathrm{~m}$ to $2500 \mathrm{~m}$. Drilling can take several weeks or months. The appropriate large equipment is used for drilling. It is also necessary to build access roads, drilling rigs, water pipelines, waste dumps and waste disposal/processing infrastructures. Construction of access roads to the drilling places can include deforestation and destruction of vegetation. Hence, drilling and well testing have the following impacts:

- Land disturbance

- Solid and liquid waste disposal, and gases discharge

- Increased noise level

- Increased traffic

- Disturbance in natural features, vegetation, habitat, Wildlife

- Workers' health

- Social impacts

Typical noise levels are:

- Air drilling - $120 \mathrm{~dB}$ (85 dB with suitable silencers);

- Discharging wells after drilling - up to $120 \mathrm{~dB}$;

- Well testing - 70-110 dB (with suitable silencers);

- Operation of heavy machinery - up to $90 \mathrm{~dB}$;

- Well bleeding - $85 \mathrm{~dB}$;

- Mud drilling - $80 \mathrm{~dB}$;

- Operation of diesel machines (provide electricity) - up to $55 \mathrm{~dB}$ with silencers.

- realising of high-pressure steam through a silencer - 70 $\mathrm{dB}$ to $110 \mathrm{~dB}$ during well testing

- The cumulative noise impact depends on the total number of wells under testing, usually over a period of several months. Bulldozers and trucks mainly cause the noise during construction and demolition during road and power plant construction.

- Main sources of noise during normal power plant operation are cooling towers, power house, and transformer. Water-cooled towers have higher noise emissions than air-cooled condensers

It is important to point out that the latest technical solutions mitigate the negative impact (compact rig environments, top drive, electrically driven pumps, waste processing and gas abatement lines...).

\subsection{Mass Withdrawal}

Large-scale geothermal systems with hightemperature liquid-dominated exploitation involve the withdrawal of large quantities of geothermal fluid. Even if all the used liquid is re-injected, it may cause a large loss of liquid (up to $30 \%$ ) related to the discharge of water vapour into the air from the power station. The main repercussions of the mass loss in the geothermal field are the generation of a two-phase zone (steam and water) in the upper part of the field. As extraction proceeds, the zone increases in size and pressure decreases. For example, at Wairakei, pressures decreased approximately by $0,5 \mathrm{MPa}$ during the drilling phase and additionally by $1,7 \mathrm{MPa}$ during the first 10 years of power production.

\subsection{Water Use and Consumption}

In classical power plants, water is the most used in a steam turbine and to discharge heat from the condenser. In gasification plants, water is used as a source of hydrogen in the production of gas that burns and drives gas turbines. Hydro power plants are powered by water that can flow from the lake or river. In geothermal power plants, fresh water is used for drilling wells, and in some technological solutions for the discharge of heat from the condenser.

Water is also used in the production phase of the fuels that are used for power generation. Irrigation water is typically used to grow the energy crops for fuel production. In addition, a significant amount of water is needed for obtaining and processing coal, natural gas and nuclear fuels.

In literature, the amount of water consumption usually refers to the operational phase of power plant life cycle. However, there are two exceptions where water consumption is significant in other stages of the life cycle. The first exception relates to the construction phase of geothermal plants. A considerable amount of water is consumed when drilling wells, which is also included in total water consumption. Total consumption of water to produce $1 \mathrm{~m}$ well is approximately $5 \mathrm{~m}^{3}$ to $30 \mathrm{~m}^{3}$, depending on the technology used, geology and number of liner sand depth [4].

For a geothermal power plant, the use of fresh water depends on the size of the power plant, the technology applied, the working temperatures and cooling variant. Binary power plants use a small amount of water because air-cooling is applied. Water is consumed in small amounts during an operation to minimize scaling and to manage dissolved solids [4]. Due to the comparably lower steam quantity and the higher outlet temperatures of fluid, waterbased cooling is less demanding than for fossil fuel-based boilers or nuclear power plants. However, most geothermal plants can use freshwater for cooling or geothermal fluid. Using geothermal fluid instead of fresh water reduces total water consumption [5]. The life-cycle water consumption for electricity generation of the different power plant is shown in Fig. 2.

In the cycle of electricity generation, most water is consumed by cooling systems and therefore they have a significant potential to reduce the consumption of fresh water [6]. Lack of freshwater for cooling in power plants, 
as well as the application of $\mathrm{CO}_{2}$ capture units, can be expected in the near future [7].

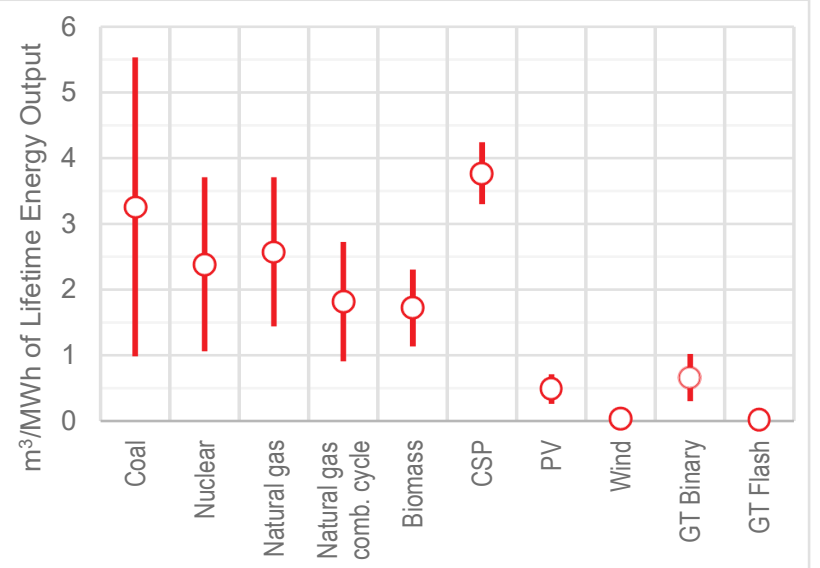

Figure 2 Life-cycle water consumption for power generation [4]

There are great efforts to optimize the efficiency of energy and water use through different approaches, such as a series-parallel configuration of coolers (return temperature and flow rate) [8], a nonlinear uncertain system's algorithm [9] and a sustainability risk index [10]. Reduction of water consumption in a cooling tower can be achieved by the use of coolant loops that reuse or recycle water. Approximately $90 \%$ water consumption is for steam cooling that comes out of the turbine. Dry cooling is considered the best approach to reducing water consumption for thermal power plants. Reduction in water consumption is more than $75 \%$ when dry cooling towers are compared with wet recirculation cooling towers. Incorporating air coolers in the water cooling system is an effective way to reduce heat load and water consumption, as well as preventing system fouling [11].

Direct contact type of condensers for the geothermal power plant mix the exhaust water with spent steam in the open chamber. The condensation process takes place on a series of perforated plates. A mixture of water and condensate drains to the cooling towers where it recycles as circulating water. The non-condensable gases such as hydrogen sulphide are thereby removed.

Based on previous condenser research related to ocean thermal energy conversion, advanced direct contact condenser is developed for more effectively condensing spent steam. In this system, perforated plates are replaced with a sophisticated structured packing. This can improve power production efficiency by $5 \%$.

Energy efficiency in the cooling system is also being considered. Due to friction and pressure drop, a great amount of energy is lost. New materials and surface treatment methods are being explored to improve heat transfer and friction reduction, which can increase energy efficiency by as much as $10 \%[12,13]$.

A study by Mekonnen et al. [14] estimated the water consumption footprint of heat and electricity sector in 2035 for five energy scenarios. They found that by 2035 water footprint would increase in the sector of heat and electricity production if there is no major investment in renewable energy sources, including wind, solar and geothermal energy. It is anticipated that increasing the share of renewable energy sources up to $19.6 \%$ of total electricity production by 2035 will significantly reduce the water footprint of the heat and electricity production sector.

\subsection{Waste Liquid Disposal}

Part of the wastewater of the geothermal power plant is the geothermal fluid used in the process. Of course, if there are pumps that push the fluid back into the ground, then part of the wastewater is reduced. A small part of the wastewater also consists of water generated during drilling, equipping and production drilling. The composition of geothermal water depends largely on the individual field and well, while the share of the individual compounds in geothermal water is directly related to the water temperature. In the water vapour dominant geothermal fields, most pollutants are in a steam condition and surface water contamination is easier to control than in the water dominant reservoirs. The most common are chlorides of sodium, potassium, and calcium, while in smaller amounts are present carbonates, sulphates, magnesium, lithium, and mercury. In geothermal water in Croatia, the dissolved mineral content varies from $1 \mathrm{~g} / 1$ to $24 \mathrm{~g} / 1$, while chlorine $13,25 \mathrm{~g} / 1$ and sodium 8,76 $\mathrm{g} / 1$ are the most common elements.

If the geothermal waters were to be discharged uncontrolled into the environment, they would pollute a surface and groundwater. Due to changes in the biological potential, it would lead to a loss of water flow functions. Water after chemical neutralization is deposited in a special pit or after purification is returned to the process.

In the binary power plant, the only impact on the environment takes place at the heat rejection side of the plant. The geothermal water heat is transferred to a secondary working fluid, which is usually an organic liquid with a low boiling point and high vapour pressure compared to water at a certain temperature. The cooled geothermal water is then re-injected into the ground. This means that the plant comprises two completely separate parts: geothermal fluid circuit and power cycle. Consequently, the geothermal fluid does not come into contact with the environment.

For the optimum functioning of the power plant and the preservation of the pressure and temperature inside the borehole, it is important that the utilized geothermal water that is returned through the wells in the underground is not colder than $70^{\circ} \mathrm{C}$. If the water is cooler, there is a gradual cooling of geothermal water and the pressure drop within the wells, and such wells are unusable for several years. For the same reason, the reinjection wells must be far enough from the production wells (for example $2 \mathrm{~km}$ to 3 $\mathrm{km})$. Furthermore, the working fluid is completely sealed inside the tube, heat exchanger and turbine so that it is never exposed to the environment.

\subsection{Solid Waste Production}

The total amount of solid waste produced is generally small and in that sense has no significant impact on the environment. Solid waste can be classified into the following groups $[15,16]$ :

- Drilling residues such as cuttings, cement residues, drilling muds, 
- Chemical sediment in tubes and vessels, scale remainder which also contains heavy metal sand,

- Deposit in cooling towers, possibly contaminated with mercury,

- The wasted material, sediments, activated carbon, material from treatment systems,

- General waste associated with the commercial operation.

In addition to the negative impacts of solid waste, there are also positive effects: the separation of metals and minerals as by-products, which can be profitable for the use of geothermal energy. Silica, lithium, and zinc are the mineral by-products that have the greatest potential to be economically extracted.

Mercury is not present in every geothermal field. However, if mercury is present in the geothermal fluid, the production of energy may involve mercury emissions, depending on the technology used. Binary power plants do not emit any mercury because of the closed geothermal water loop. In other types of power plants, by using mercury-emission abatement equipment it is possible to reduce emissions by $90 \%$ or more.

Geothermal plants usually do not have high arsenic emissions although arsenic is common to volcanic materials. If arsenic is present in a geothermal fluid, it is abated together with hydrogen sulphate and most often ends up in a solid form in the sludge.

Silica is a by-product of geothermal power production from certain brine reservoirs. Silica can be found in the treated wastewaters or effluents that are the by-products of drilling operations. Silica is usually separated from water and silica sludge deposits at the site. Silica does not pose any risk to the environment. The precipitation of dissolved and colloidal silica can be a problem in the cooling towers, and evaporating systems of power plants.

Scrubbers are reducing air emissions but they produce a watery sludge that contains different materials, including chlorides, sulphur, silica, vanadium, mercury, arsenic, nickel, and other heavy metals. This toxic sludge must be disposed at appropriate locations for hazardous waste [13]. Management of the sludge is very important in order to avoid potential environmental impacts. Electro-kinetic water treatment technologies typically produce less waste volume, but higher concentrations.

\subsection{Waste Gas Emission}

The difference between open-loop and closed-loop geothermal systems is important in terms of emissions to air. In closed-loop systems, the gases removed from the borehole are not released into the air and are reinjected into the ground after realising their heat, so emissions to air are insignificant. The gas emissions of closed-loop systems refer only to leakage of working fluid, which is usually a very small percentage of the total annual fluid volume $(<1 \%)$. Open-loop systems may discharge fine solid particles and non-condensable gases into the atmosphere. This includes hydrogen sulphide, carbon dioxide, methane, ammonia, hydrogen and boron to the air. Gas composition and concentrations vary not only between fields but also from well to well within a field.
The discharge is mainly through a cooling tower. Gaseous and particulate discharges during drilling, cleanouts, bleeding, testing and from the line valves and degassing wastewater are not significant. Typical geothermal power plants that use steam or hot water for the production of electricity emit about $5 \%$ of carbon dioxide $\left(\mathrm{CO}_{2}\right), 1 \%$ sulphur dioxide $\left(\mathrm{SO}_{2}\right.$ and less than $1 \%$ nitrogen oxide $\left(\mathrm{NO}_{\mathrm{x}}\right)$ emitted by the same power plant fired by coal [17].

Tab. 2 provides an overview of geothermal fields around the world and their gas composition [18].

Table 2 Non-condensable gas composition of different geothermal fields

\begin{tabular}{|l|c|c|c|c|c|}
\hline \multirow{2}{*}{\multicolumn{1}{|c|}{ Geothermal Field }} & \multicolumn{5}{|c|}{ Gas Composition (\% weight) } \\
\cline { 2 - 6 } & $\mathrm{CO}_{2}$ & $\mathrm{H}_{2} \mathrm{~S}$ & $\mathrm{~N}_{2}$ & $\mathrm{H}_{2}$ & $\mathrm{CH}_{4}$ \\
\hline Olkaria (Kenya) & 80,67 & 9,28 & 1,72 & 7,68 & 0,65 \\
\hline Wairakei (New Zealand) & 88,67 & 10,02 & 0,80 & 0,24 & 0,25 \\
\hline Ngawha (New Zealand) & 95,88 & 1,01 & 0,30 & 0,28 & 2,52 \\
\hline Zunil (Guatemala) & 96,24 & 2,51 & 0,80 & 0,43 & 0,02 \\
\hline Miravalles (Costa Rica) & 98,24 & 0,60 & 0,80 & 0,33 & 0,03 \\
\hline Svartsengi (Iceland) & 92,54 & 2,32 & 4,98 & 0,10 & 0,06 \\
\hline Hveragerdi (Iceland) & 75,32 & 7,11 & 15,8 & 1,62 & 0,15 \\
\hline Krafla (Iceland) & 86,16 & 9,29 & 2,62 & 1,87 & 0,06 \\
\hline Hellisheiði (Iceland) & 72,55 & 23,53 & 1,96 & N/A & N/A \\
\hline
\end{tabular}

The presence of $\mathrm{CO}_{2}$, or any other greenhouse gases in geothermal steam leads to a significant decrease in power plan efficiency. Available work at the turbine inlet depends on NCG (Non-Condensable Gases) content more strongly than turbine inlet temperature. As Gokcen and Yildirim [19] point out maximum exergy drop encountered for $25 \%$ non-condensable gases content is about $22 \%$ comparing with zero non-condensable gases. Available work loss at the turbine inlet is $0,86 \%$ for each $1 \%$ non-condensable gases increase. If the condensation phase takes into account the effects of non-condensing gases, the output net power of the geothermal plant will fall even further.

\subsubsection{Carbon Dioxide}

Carbon dioxide is the main greenhouse gas emission from geothermal power plants. These quantities are small compared to the fossil fuel power plant emission. Some geothermal reservoirs contain different amounts of NCG including $\mathrm{CO}_{2}$. Geothermal steam is usually condensed after passing through the steam turbine, but $\mathrm{CO}_{2}$ does not condense. It is pulled to the exhaust system where it is discharged into the air through the cooling towers. The volume of $\mathrm{CO}_{2}$ discharged into the air varies depending on plant design (Fig. 3).

Binary plants emit no $\mathrm{CO}_{2}$ because geothermal fluids in this system are never exposed to the atmosphere. For example, geothermal power plant Draškovec will extract hot water from depths of 1800 to 2300 meters, but also all the gases that are completely dissolved in it, mainly methane. It will use as energy the heat of water and the energy of geothermal gases for energy production. Any carbon dioxide that will arise in the production process or is partially dissolved in the geothermal water will be driven back through the wells into the same geothermal reservoir and $\mathrm{CO}_{2}$ emission will be zero.

An equivalent coal-fired power plant, the $10 \mathrm{MW}$ net power, would emit from $96000 \mathrm{t} / \mathrm{yr}$ to $150000 \mathrm{t} / \mathrm{yr}$ of $\mathrm{CO}_{2}$ depending on the type of coal and the efficiency of the plant. 


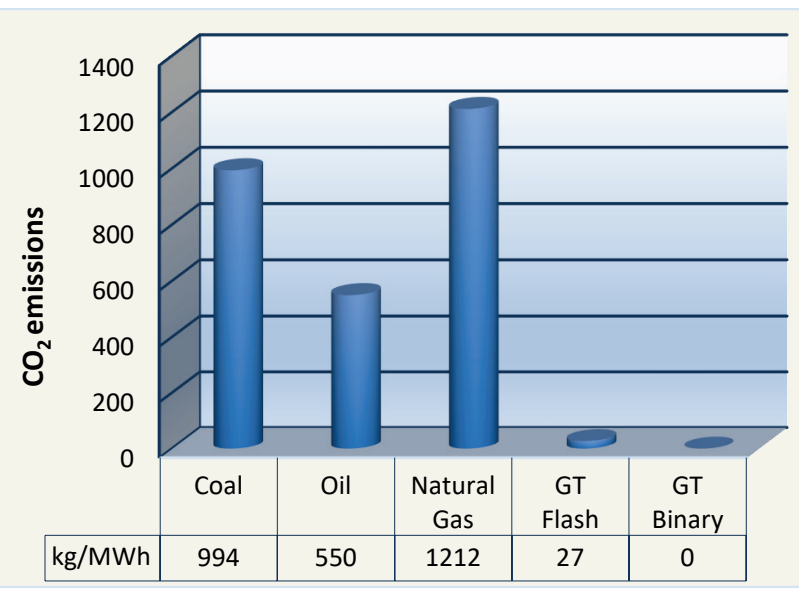

Figure 3 The $\mathrm{CO}_{2}$ released into the atmosphere by the power plant [20]

Emissions of carbon dioxide from the geothermal field can be reduced by the cascade exploitation of geothermal energy. If one of the cascade users is a greenhouse, $\mathrm{CO}_{2}$ can be used for plant purposes.

\subsubsection{Hydrogen Sulphide}

Emissions of $\mathrm{H}_{2} \mathrm{~S}$ can significantly vary according to individual fields, depending on the amount of $\mathrm{H}_{2} \mathrm{~S}$ in the geothermal fluid (Tab. 2) and the type of plant applied.

Hydrogen sulphide $\left(\mathrm{H}_{2} \mathrm{~S}\right)$ is as usual abated at geothermal power plants. The result is the conversion of over $99.9 \%$ of $\mathrm{H}_{2} \mathrm{~S}$ from geothermal gases into elemental sulphur, which can be used as a soil or fertilizer additive. In recent decades many processes for $\mathrm{H}_{2} \mathrm{~S}$ removal have been developed. Two systems that are commonly used to reduce emissions of $\mathrm{H}_{2} \mathrm{~S}$ are Stretford and LO-CAT. The choice of a suitable abatement method requires inter alia the analysis of several variables such as geothermal fluid composition, process efficiency, economic costeffectiveness and geothermal power plant design. Binary and flash-binary combined cycle do not emit any $\mathrm{H}_{2} \mathrm{~S}$ at all. Since 1976, $\mathrm{H}_{2} \mathrm{~S}$ emissions have decreased from $862 \mathrm{~kg} / \mathrm{hr}$ to $91 \mathrm{~kg} / \mathrm{hr}$ or less, although electricity production from geothermal energy has increased from $500 \mathrm{MW}$ to over 14 GW in January 2018.

\subsubsection{Other Gases}

Because geothermal plants do not burn fossil fuel, emitting of nitrogen oxides is at a very low level. Actually, in most cases, they emit no nitrogen oxides at all [20]. These small quantities of $\mathrm{NO}_{x}$ can result from the combustion of $\mathrm{H}_{2} \mathrm{~S}$ from $\mathrm{H}_{2} \mathrm{~S}$ abatement system. The amount of NOx released into the atmosphere from different power plants is shown in Fig. 4.

Geothermal gases may contain ammonia $\left(\mathrm{NH}_{3}\right)$, mercury $(\mathrm{Hg})$ in trace amounts, boron (B) vapour and hydrocarbons such as methane $\left(\mathrm{CH}_{4}\right)$. Ammonia causes irritation of the eyes, nose passages and respiratory tracts in concentrations of $5 \mathrm{ppm}$ to $32 \mathrm{ppm}$. Inhaling mercury may cause neurological disorders.

Boron irritates the skin and mucous membranes and is phytotoxic at relatively low concentrations. The boron toxicity has a negative effect on the metabolic function of the plant. There is a decrease in yield due to the death of plant tissues, the active area of the leaves and reduction of photosynthesis activity. However, boron is emitted in very low amounts and therefore does not present a danger to human health. In geothermal steam systems, boron is present as highly soluble boric acid. Combined with ammonia boron makes up deposits of white crystalline salt on surfaces of equipment exposed to the geothermal fluid. Because of high solubility, almost all borate entering the geothermal plant are dissolved in vapour condensate and leaving the plant through the cooling tower.

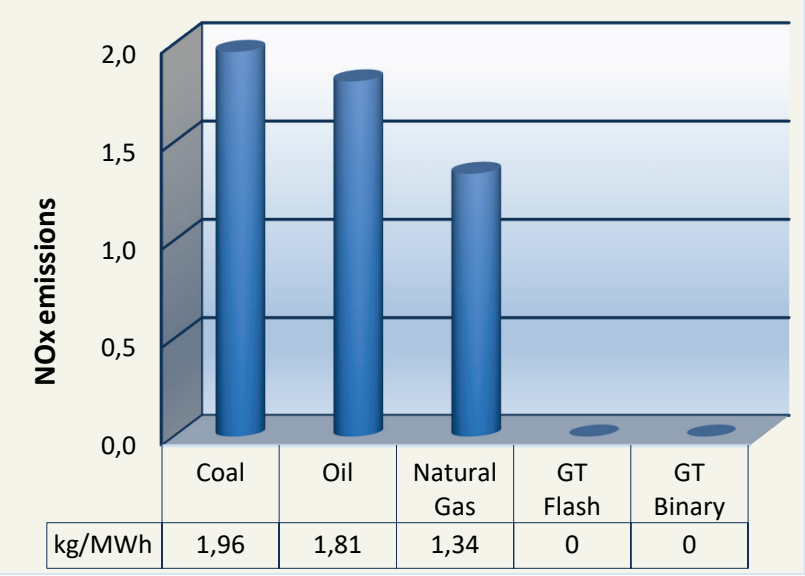

Figure 4 The NOx released into the atmosphere by the power plant [20]

New cooling towers have installed high-efficiency drift eliminators for particulate control regardless of boron content in the water that reduces boron emissions. Boron emissions are usually not regulated by law so boron compounds can be emitted in a cooling tower drift because they do not have an impact on the environment.

Binary plants use low-boiling liquid, usually isopentane, which can escape from the plant for a certain period of time. Leak values up to $4000 \mathrm{ppm}$ were recorded.

From fewer represented gases the worst is radioactive radon with $4,85 \mathrm{~Bq} / 1$ to $17 \mathrm{~Bq} / 1$ on Croatian territory, but these values in the environment are not dangerous for human health.

Although geothermal power plants do not emit $\mathrm{SO}_{2}$ directly in the atmosphere, once $\mathrm{H}_{2} \mathrm{~S}$ is discharged as a gas, it spreads into the atmosphere and typically chemically reacts to $\mathrm{SO}_{2}$ and sulphuric acid. So, each $\mathrm{SO}_{2}$ emission associated with geothermal energy comes from the $\mathrm{H}_{2} \mathrm{~S}$ emission.

\subsection{Particulate Matter}

Geothermal power plants emit almost no particulate matter while coal and oil power plants produce hundreds of tons of particulate matter annually. A small quantity of particulate matter is emitted from the cooling tower when the water is evaporated as part of the cooling cycle. However, these quantities are quite small in comparison to oil or coal power plants that have burning processes and cooling towers.

\subsection{Depletion of Groundwater}

Above most of the high-temperature geothermal fields, there is a layer of cold groundwater. If the exploitation of geothermal fluid leads to a large pressure drop in the reservoir, the cold groundwater can penetrate into the 
upper part of the reservoir in places where there are suitable high passage paths. Such a phenomenon is called a cold downflow. Downflow may lead to a drop in the groundwater level if the lateral permeability of the rock is small in the area where the groundwater is located. For example, this occurred at Wairakei power plant where a localised drop is more than $30 \mathrm{~m}$ in groundwater level.

\subsection{Ground Deformation}

Ground deformation is another important point when examining the use of geothermal power plants. Pumping geothermal water from the depths of the earth can disrupt the delicate balance that exists between layers of earth. For dry steam power plants, it is not such a big problem, because the rocks are relatively self-sufficient, and the dry steam only fills the space. However, in the fluid power plants, the fluid, and the pressure mainly support the rocks. Thus, by fluid retraction, the pressure is maintained backward and prevents the occurrence of landslides and damage to objects on the surface. In Croatia, the foundations are at a great depth and there is not too much danger of landslides. Horizontal displacement of the land may also appear. Such horizontal displacement of the land can have serious consequences on the stability of buildings, pipelines, wells and drains in the geothermal field. If the geothermal field is located near a residential area, the land subsidence can lead to instability of dwellings and other buildings.

\subsection{Ground Temperature Changes}

The creation and expansion of the two-phase zone in the exploitation of the geothermal field with dominant hot water can affect the thermal flow. Water vapour is much more mobile than water and can pass through small cracks that are impermeable to water, and through larger cracks it moves faster than water. Thus, the creation and movement of water vapour can increase the heat flow resulting in an increase in soil temperature so that vegetation becomes stressed or killed.

\subsection{Microclimatic Effects}

Even with geothermal plants that apply completely reinjection of geothermal media, considerable amounts of gases (mostly water vapour) can be released into the atmosphere. Such water vapour discharge may have a significant impact on the climate in the power plant area, depending on land topography, wind and precipitation characteristics. Under certain conditions, increased fog, cloud or rain may occur. Microclimatic effects mainly relate to the exploitation of high-temperature geothermal fluids. Utilization of low-temperature geothermal sources usually does not lead to significant microclimatic effects.

\subsection{Land Use}

Like other power plants, the geothermal power plant occupies a certain area of land. This occupation may be temporary (during construction, reclamation) or permanent (during power plant operation) [21].
Geothermal power plants are usually built at the site of geothermal fields because long pipelines are expensive, and the pressure and temperature drop may be significant. Determined land area is required for well pads, power station buildings, pipelines, cooling towers and electrical switchyard. The total surface area covered by the construction of a power plant is considerably larger than the area required for the aforementioned components of the plant. For example, at field Cerro Prieto (Mexico) the surface area covered by the well pads ( $12 \mathrm{ha}$ ) is only $2 \%$ of the total surface area (540 ha) covering the well pads and the power station (180 MWe).

The land between the well pads and pipelines can in many cases continue to be used for other purposes, although it is in some locations impractical.

The amount of surface area needed for a geothermal power plant varies depending on the properties of the geothermal source, the type of applied energy conversion scheme, the amount of power capacity, the type of cooling system, the locations of wells, pipelines, the substation and auxiliary building [22] (see Fig. 5).

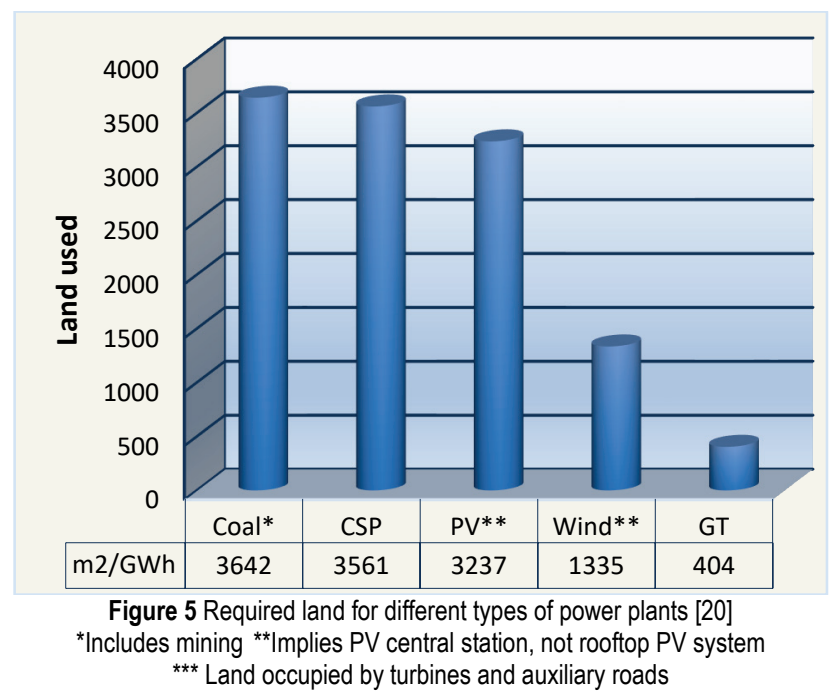

An estimate of the average amount of "land disruption" during the construction of a power plant of $50 \mathrm{MW}$ is about of $0,85 \mathrm{~km}^{2}$. This includes six well pads (with single and multiple wells, e.g. by employing advanced directional or slant drilling technology), approximately $0,4 \mathrm{~km}$ road per well and $8 \mathrm{~km}$ to $80 \mathrm{~km}$ long piping (about $15 \mathrm{~m}$ corridors, the required minimum distance of wells to avoid interference is usually $200 \mathrm{~m}$ to $300 \mathrm{~m}$ ).

However, a power plant of $50 \mathrm{MW}$ can have up to 25 production and 10 reinjection wells. Binary-type plants are much smaller plants and usually range from 0,5 MWe to $10 \mathrm{MWe}$. In addition, the use of geothermal resources does not require long-distance fuel transportation by pipeline, rail, highway or ocean tankers.

\subsubsection{Subsidence}

Subsidence, or the slow, downward ground deformation, is associated with a pressure drop in the geothermal reservoir. The effective mitigating technique is reinjection of used fluid in the reservoir. 


\subsubsection{Induced Seismicity}

Extraction of geothermal energy and re-injection of used fluid can be associated with the occurrence of mild seismic tremor known as micro-earthquakes. Usually, people cannot notice these low magnitude events, but geothermal companies often record them.

\subsection{Waste Heat}

All heat energy-converting systems produce waste heat that can have a significant share (Fig. 6). This also applies to geothermal energy. The amount of waste heat depends on the applied technology. Geothermal power plants emit significantly greater amounts of waste heat into the environment because of lower efficiency. The size of cooling towers reduced to unit capacity for geothermal power plants is considerably higher than for power plants using other energy sources.

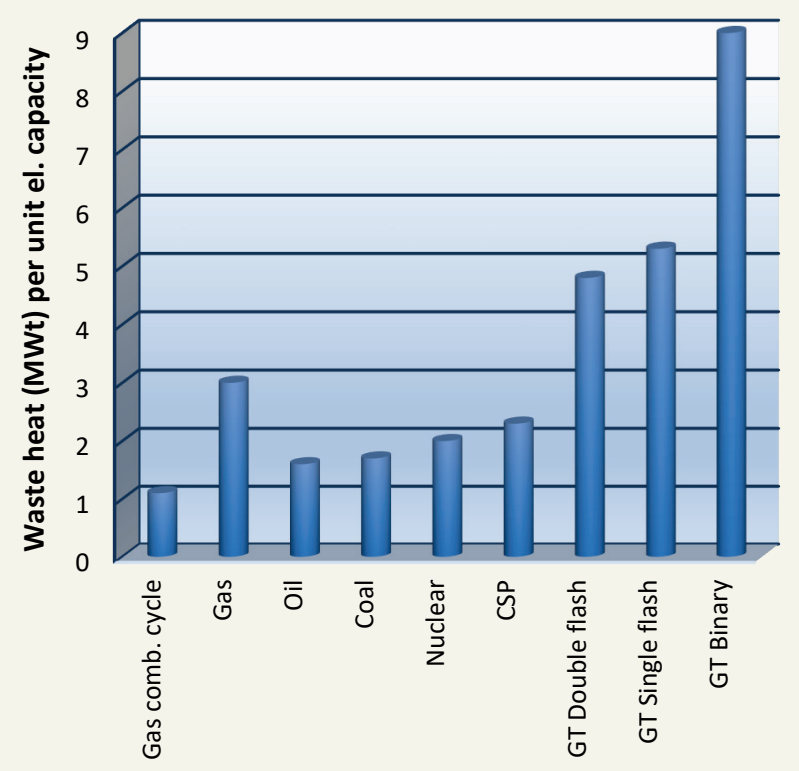

Figure 6 Waste heat (MWt) per unit electric capacity (MWe) for different processes of power generation [24]

Geothermal power plants discharge the waste heat into the atmosphere, lakes or natural water bodies [23].

The energy conversion efficiency depends mainly on the geothermal fluid temperature. The binary cycle power plant has a lower efficiency, and hence the comparatively large amount of waste heat. If the waste heat is utilized for direct heating (eg. for district heating or greenhouse), not only the efficiency of the geothermal plant will be greater, but also significant environmental benefits will result due to lower emissions of waste heat into the environment.

\subsection{Visual Intrusion}

Geothermal plants must be located near geothermal resources, which causes the accommodation facilities. Visual disturbances are most pronounced when drilling wells and building objects, for example, when tall drill rigs are placed. Geothermal plants mostly have a low profile and do not have high chimneys like coal or oil-fired power plants. However, their impact on the visual appearance of the environment can be significant, because geothermal fields are often located in areas of extraordinary natural beauty or thermal objects, thus becoming a tourist attraction.

\section{CONCLUSION}

Geothermal power plants are environmentally friendly because they use renewable energy, which, unlike wind and solar energy, is available 24 hours a day. The geothermal power plant has very low emission levels, especially compared to conventional power plants using fossil fuels. Geothermal binary power plants, which are recently most often built, have a minimal emission of particles and almost zero emissions of greenhouse gases. If lifecycle emissions are analysed, it can be concluded that geothermal power plants of binary type produce energy with minimal environmental impact.

Not only emissions are minimal but the land footprint and freshwater use are tiny as well. Geothermal plants occupy very little land area compared to other sources of energy, especially compared to other renewable energy sources.

While currently used at only a fraction of its potential, due to previously explained, geothermal energy can significantly participate in meeting the energy needs of the $21^{\text {st }}$ century.

Although existing studies do not show extreme impacts of geothermal energy utilisation, monitoring mechanisms should be employed to mitigate against any effects that may emerge in the future. In addition, this information will also be of benefit to the public (including scientists and conservationists) and decision makers involved in policy developments who are becoming increasingly aware of and are questioning the effects of these emissions on the environment. Baseline data and continuous monitoring of these emissions within geothermal power plants will thus assure social acceptability of such projects in the promotion of sustainable development.

\section{REFERENCES}

[1] Guzovic, Z., Loncar, D., \& Ferdelji, N. (2010). Possibilities of electricity generation in the Republic of Croatia by means of geothermal energy. Energy, 35(8), 3429-3440. https://doi.org/10.1016/j.energy.2010.04.036

[2] Hunt, T. M. (2000). Five lectures on environmental effects of geothermal utilization. Geothermal training programme. The United Nations University, Reports 2000. Number 1, 922.

[3] Bayer, P., Rybach, L., Blum, F., \& Brauchler, R. (2013). Review of life-cycle environmental effects of geothermal power generation, Renewable and Sustainable Energy Reviews, 26, 446-463. https://doi.org/10.1016/j.rser.2013.05.039

[4] Clark, C. E., Harto, C. B., Sullivan, J. L., \& Wang, M. Q. (2011). Water use in the development and operation of geothermal power plants. Energy System Division, Argonne National Laboratory. https://doi.org/10.2172/1013997

[5] Macknick, J., Newmark, R., Heath, G., \& Hallett K.C. (2012). Operational water consumption and withdrawal factors for electricity generating technologies: a review of existing literature. Environmental Research Letters, 7 045802, 1-10. https://doi.org/10.1088/1748-9326/7/4/045802 
[6] Pan, S-Y, Snyder, S. W., Packman, A. I., Lin, Y. J., \& Chiang, P-C. (2018). Cooling water use in thermoelectric power generation and its associated challenges for addressing water-energy nexus. Water-Energy Nexus, 1, 2641. https://doi.org/10.1016/j.wen.2018.04.002

[7] Murrant, D., Quinn, A., Chapman, L., \& Heaton, C. (2017). Water use of the UK thermal electricity generation fleet by 2050: Part 2 quantifying the problem. Energy Policy, 108, 859-874. https://doi.org/10.1016/j.enpol.2017.03.047

[8] Sun, J., Feng, X., \& Wang, Y. (2015). Cooling-water system optimisation with a novel two-step sequential method. Applied Thermal Engineering, 89, 1006-1013. https://doi.org/10.1016/j.applthermaleng.2015.01.012

[9] Salazar, J. M., Zitney, S. E., \& Diwekar, U. M. (2011). Minimization of water consumption under uncertainty for a pulverized coal power plant. Environmental Science \& Technology, 45(10), 4645-4651. https://doi.org/10.1021/es1043062

[10] Roy, S. B., Chen, L., Girvetz, E. H., Maurer, E. P., Mills, W. B., \& Grieb, T. M. (2012). Projecting water withdrawal and supply for future decades in the U.S. under climate change scenarios. Environmental Science \& Technology, 46(5), 2545-2556. https://doi.org/10.1021/es2030774

[11] Ma, J., Wang, Y., Feng, X., \& Xu, D. (2018). Synthesis cooling water system with air coolers. Chemical Engineering Research and Design, 131, 643-655. https://doi.org/10.1016/j.cherd.2017.10.020

[12] Attinger, D., Frankiewicz, C., Betz, A. R., Schutzius, T. M., Ganguly, R., Das, A., Kim, C.-J., \& Megaridis, C. M. (2014). Surface engineering for phase change heat transfer: A review. MRS Energy \& Sustainability, 1, 1-40. https://doi.org/10.1557/mre.2014.9

[13] Zhang, S., Zeng, X., Igartua, A., Rodriguez-Vidal, E., \& van der Heide, E. (2017). Texture design for reducing tactile friction independent of sliding orientation on stainless steel sheet. Tribology Letters, 65:89. https://doi.org/10.1007/s11249-017-0869-x

[14] Mekonnen, M. M., Gerbens-Leenes, P. W., \& Hoekstra, A. Y. (2016). Future electricity: The challenge of reducing both carbon and water footprint. Science of the Total Environment, 569-570, 1282-1288. https://doi.org/10.1016/j.scitotenv.2016.06.204

[15] Brophy, P. (1997). Environmental advantages to the utilization of geothermal energy. Renewable Energy, 10(23), 367-377. https://doi.org/10.1016/0960-1481(96)00094-8

[16] Arnórsson, S. (2004). Environmental impact of geothermal energy utilization. Geological Society, London, Special Publications, 236, 297-336. https://doi.org/10.1144/GSL.SP.2004.236.01.18

[17] Duffield, W. \& Sass, J. (2003). Geothermal Energy - Clean Power from the Earth's Heat. U.S. Geological Survey. https://doi.org/10.3133/cir1249

[18] Chaves, R. B. (1996). Geothermal gases as a source of commercial $\mathrm{CO}_{2}$, in Miravalles, Costa Rica and Haedarendi, Iceland. United Nations University, Reykjavik, Iceland, 3.

[19] Gokcen, G. \& Yildirim, N. (2008). Effect of NonCondensable Gases on geothermal power plant performance. Case study: Kizildere Geothermal Power Plant-Turkey. International Journal of Exergy, 5(5-6), 684-695. https://doi.org/10.1504//JEX.2008.020832

[20] Kagel, A. (2007). A Guide to Geothermal Energy and the Environment. DC: Geothermal Energy Association, Washington http://geo-energy.org/pdf/reports/AGuideto GeothermalEnergyandtheEnvironment10.6.10.pdf

[21] Rybach L. (2005). Environmental aspects of geothermal development and utilization, and related legal, institutional and social implications. In: K Popovski, editor, Proceedings of the world geothermal congress, Pre and post congress courses; 24-29 April, 2005 ed., Antalya, Turkey, pp. 27.
[22] National Renewable Energy Laboratory (NREL). 2012. Renewable Electricity Futures Study.

[23] Rybach, L. \& Kohl, T. (2004). Waste heat problems and solutions in geothermal energy. Energy, Waste and the Environment, Geological Society, London, Special Publications, 236, 369-380,

DOI: 10.1144/GSL.SP.2004.236.01.21

[24] Rybach, L. (2005). Environmental Aspects of Geothermal Energy Development and Utilisation and Related Legal, Institutional and Social Implications. World Geothermal Congress (WGC 2005). Pre and Post Congress Short Courses. Izmir and Antalya, Turkey, April 2005.

\section{Contact information:}

Mladen BOŠNJAKOVIĆ, PhD, Assistant Professor

(Corresponding author)

College of Slavonski Brod,

Dr. Mile Budaka 1, 35000 Slavonski Brod, Croatia

mladen.bosnjakovic@vusb.hr

Marinko STOJKOV, PhD, Full Professor

Mechanical Engineering Faculty in Slavonski Brod,

Trg Ivane Brlić Mažuranić 2, 35000 Slavonski Brod, Croatia

mstojkov@sfsb.hr

Mate JURJEVIĆ, PhD, Associate Professor

University of Dubrovnik, Maritime Department,

Ćira Carića 4, 20000 Dubrovnik, Croatia

mjurjevic@unidu.hr 